\title{
Detection of changes in flow regime of rivers in Poland
}

\author{
Dariusz Wrzesiński, Leszek Sobkowiak* \\ Adam Mickiewicz University, Institute of Physical Geography and Environmental Planning, Chair of Hydrology and Water \\ Management, Bogumiła Krygowskiego 10 str., 61-680 Poznań, Poland. \\ * Corresponding author. E-mail: lesob@amu.edu.pl
}

\begin{abstract}
The aim of this study is to detect changes in flow regime of rivers in Poland. On the basis of daily discharges recorded in 1951-2010 at 159 gauging stations located on 94 rivers regularities in the variability of the river flow characteristics in the multi-year period and in the annual cycle were identified and also their spatial uniformity was examined. In order to identify changes in the characteristics of river regime, similarities of empirical distribution functions of the 5-day sets (pentads) of discharges were analyzed and the percent shares of similar and dissimilar distributions of the 5-day discharge frequencies in the successive 20-year sub-periods were compared with the average values of discharges recorded in 1951-2010. Three alternative methods of river classification were employed and in the classification procedure use was made of the Ward's hierarchical clustering method. This resulted in identification of groups of rivers different in terms of the degree of transformation of their hydrological regimes in the multi-year and annual patterns.
\end{abstract}

Keywords: Flow regime; Detection of changes; Empirical distribution function; Typological classification; Ward's hierarchical clustering method.

\section{INTRODUCTION}

Identification and understanding of the multi-year changeability (or stability) of river regime is a key issue due to the present changes of climate and an increasing human impact on the water environment. River regime is a significant indicator that can be applied to identify spatial and temporal changes of river flow, its structure and seasonality, and also to determine the present and prospective water deficits.

According to Gutry-Korycka (2001) hydrological regime is a pattern of changes of all phenomena occurring in a river. It determines the state and response of a river system in relation to the climatic conditions and physical-geographical characteristics of its basin. Rotnicka (1988) defines the river regime as a kind of river discharges and their temporal structure in an average annual cycle. That structure consists of so-called hydrological periods that can be used to examine river regime and thus constitute a basis for its description.

Under the influence of the changing climate and human activity river regime may be altered and ultimately changed into a different one, sometimes with a distinctively different pattern of seasonal flow. As a consequence, the previously established hydro-ecological conditions and the water use patterns in that river basin may be disturbed. Stream flow seasonality and variability and their characteristics at the global scale were investigated by Dettinger and Diaz (2000), while Stahl et al. (2010) investigated selected near-neutral catchments in Europe to predict the future streamflow trends. At regional scale Parajka et al. (2010) investigated flood regimes and their seasonal characteristics across the Alpine-Carpathian range. At countrylevel scale Merz et al. (1999) studied the problem of seasonality of floods in Austria, while Parajka et al. (2009) applied the comparative approach to analyze the seasonality of hydrological characteristics in Slovakia and Austria. Bezak et al. (2015, 2016) analyzed flood events in Slovenian streams and identified their statistical trends and seasonality, while Merz et al. (2016) attempted to separate flood-rich and flood-poor periods in 68 catchments across Germany. Gaál et al. (2012) through the comparative hydrology stressed the role of the flood timescales as an important parameter integrating a range of climate and catchment. In analyses of the effects of climate changes on the natural environment, including water resources, there is a growing number of studies on climatic factors influencing seasonal changes of flow and altering river regimes, including that by Krasovskaia and Gottschalk (1992), Krasovskaia (1995), Krasovskaia (1996), Krasovskaia and Sælthun (1997) and Wilson et al. (2012). Results of studies on the runoff changes in relation to the observed and predicted global warming were presented by Labat et al. (2004).

Due to the global warming periodic variations of river discharges are observed. This attracts attention of scholars involved in studies on changes of river regimes, as for example Westmacott and Burn (1997), Middelkoop et al. (2001), Krasovskaia and Gottschalk (2002). In this context new methodological approaches and regional syntheses deserve attention (Arnell, 1999; Gutry-Korycka and Rotnicka, 1998; Krasovskaia et al., 1999; Shorthouse and Arnell, 1999; Wrzesiński, 2008, 2010a). Arnell (1999) presented an assessment of the effects of climate change on the hydrological regime of European rivers, also Hall et al. (2014) pointed out potential drivers of flood regime changes and on that basis predicted future changes in floods in selected sub-regions of Europe. Bower et al. (2004) provided a critical analysis of methods used to establish the climatic determinants of changes of river regime, while Dynowska $(1988,1993)$ studied the anthropogenic determinants of such changes observed in rivers in Poland.

In order to identify changes in any regularity, including those in the hydrological regime (regardless of their causes), in the first stage a proper identification and description of the initial state is required. Only then, in relation to that initial state it is possible to define departures and deviations observed in a multi-year period. In defining river regime both the supervised (Dynowska, 1971; Lvovich, 1938; Pardé, 1957) and unsupervised (Gottschalk, 1985; Haines et al., 1988; Rotnicka, 1988) approaches are applied. In the supervised approach regularities in the multi-year hydrometric data series that are in accordance 
with predefined indices are sought, while in the unsupervised approach classificatory procedures (usually grouping) are used (Krasovskaia and Gottschalk, 2002; Wrzesiński, 2010a).

In that context the method of analysis and description of river regime through an identification of the temporal structure of hydrological phenomena and their changes in the annual cycle proposed by Rotnicka (1988) should be pointed out. It has been employed both in theoretical and applicative studies, among others to identify prospective changes in the river regime patterns under different scenarios of the global climate changes (Gutry-Korycka and Rotnicka, 1998). Moreover, that method is a very useful tool in determining the stability of the river regime characteristics, which can be altered by changing climate or human activity. Wrzesiński $(2005,2008,2011)$ applied that method to assess changes in flow regimes of rivers triggered by different intensity of the North Atlantic Oscillation (NAO) and also to detect transformations of flow regime of rivers in Poland (Wrzesiński, 2010b, 2013b).

The aim of this study is to determine changes in flow regime of rivers in Poland through identification of their variation patterns both in the multi-year and annual cycles. Changes in these river regimes were identified on the basis of analysis of similarities between the empirical distribution functions of the five-day sets of discharges (pentads) and the percent share of similar and dissimilar frequency distributions of discharges in 41 twenty-year sub-periods separated within the multi-year period 1951-2010.

\section{STUDY AREA AND DATA}

Poland with an area of 312,823 square km shows considerable differences of its environmental conditions, both climatic and hydrological, that are reflected in different river feeding conditions and in a distinctive seasonal changeability of river flow. Woś (2010) distinguished 28 climatic regions in Poland, while Dynowska and Pociask-Karteczka (1999) identified five major types of hydrological regimes of the Polish rivers, namely: nival poorly developed, nival medium developed, nival clearly developed, nival-pluvial and pluvial-nival. In addition, in Poland there is a regionally differentiated influence of the macro-scale climatic phenomena on the country's hydrometeorological elements. Therefore, rivers in Poland are exposed to different factors influencing (altering) their flow and destabilizing their regimes. These factors include natural changes, climatic variations and human activity.

The aim of this research is to detect changes in flow regime resulting not only from the natural variability of climate but also from human activity. Consequently, all the available hydrometric data were examined, regardless of their statistical homogeneity. In this study daily discharges recorded at 159 gauging stations located on 94 rivers in Poland in the multi-year period 1951-2010 were analyzed. The data were provided by the Institute of Meteorology and Water Management in Warsaw, Poland.

\section{METHODOLOGIES}

In this paper changes in river regime were determined by investigating similarities between distributions of the river discharge frequencies clustered in the 5-day sets (pentads) of each hydrological year in 41 consecutive twenty-year sub-periods and distributions of the river discharge frequencies in the whole multi-year period 1951-2010. Details of that method can be found in Wrzesiński (2010b, 2013b). The five-day period (pentad) was taken as an elementary time unit and the value of discharge was set as a grouping criterion. That criterion was described by variable $x$, defined as the frequency distribution of water discharges. The hydrological year consists of 73 pentads, each representing five values of daily discharges. The hydrological year in Poland lasts from $1^{\text {st }}$ November to $31^{\text {st }}$ October of the next year, and it is additionally divided into the winter $\left(1^{\text {st }}\right.$ November- $30^{\text {th }}$ April $)$ and summer $\left(1^{\text {st }}\right.$ May- $31^{\text {st }}$ October $)$ seasons.

In the first part of the analysis frequency distributions of discharges in the individual pentads in the multi-year period (1951-2010) and of 41 twenty-year sub-periods, each one shifted by one year (that is 1951-1970, then 1952-1971 and so on, until 1991-2010) were calculated. Therefore, for the whole 60year long observation period a 300 -element ( 5 days multiplied by 60 years) set of discharge values for each pentad was calculated. Similarly, for each 20-year interval a 100-element set was obtained. Next, the calculated discharge frequencies were cumulated in a descending order, from the highest to the lowest value intervals. On the basis of the cumulative discharge frequencies for each yearly set of pentads empirical distribution functions were computed.

For each of 73 pentads similarities between empirical distribution functions of river discharges in the multi-year 19512010 and the consecutive 20-year sub-sets were determined with the use of the non-parametric Kolmogorov-Smirnov test (Sobczyk, 2007). Results of previous studies of Wrzesiński (2013b) show that the next stage of the analysis should be modified in such a way that in order to obtain information on the tendency of changes (increase or decrease) of river flow for the compared distributions instead of calculating the absolute values of differences between the empirical distribution functions $\left(F_{n_{k}}, F_{n_{p}}\right)$, the maximum (or minimum) differences D should be computed, as follows:

$$
D=\max (\min )\left(F_{n_{k}}(x)-F_{n_{p}}(x)\right)
$$

where: $F_{n_{k}}(x)$ is empirical distribution function of the multiyear 1951-2010 set and $F_{n_{p}}(x)$ is empirical distribution function of the respective twenty-year subset.

The $\lambda$ statistic is: $\lambda=D \sqrt{n}$, where $n=\frac{n_{k} n_{p}}{n_{k}+n_{p}}, n_{k}, n_{p}$ denote the size of samples on the basis of which the empirical distribution functions were calculated. It has a Kolmogorov distribution.

Hypothesis $H_{0}$ about the goodness-of-fit of a pair of distributions was tested at the $\alpha=0.05$ and $\alpha=0.01$ significance levels. For the 300-element and 100-element samples, respectively, hypothesis $H_{0}$ was not rejected when $\lambda<\lambda_{\alpha}$, i.e. when $D \sqrt{n}<\lambda_{\alpha}$ or $D<\frac{\lambda_{\alpha}}{\sqrt{n}}$.

By substituting the critical values for $\alpha=0.05$ and $\alpha=0.01$ from the Kolmogorov distribution, we obtain the maximum and minimum differences for $D$, respectively:

$$
D_{\max }<\frac{\lambda_{0.05}}{\sqrt{n}}=\frac{1.36}{\sqrt{\frac{30000}{400}}}=0.157 \text {, }
$$




$$
\begin{aligned}
& D_{\text {min }}>\frac{\lambda_{0.05}}{\sqrt{n}}=\frac{1.36}{\sqrt{\frac{30000}{400}}}=-0.157, \\
& D_{\text {max }}<\frac{\lambda_{0.01}}{\sqrt{n}}=\frac{1.63}{\sqrt{\frac{30000}{400}}}=0.188, \\
& D_{\text {min }}>\frac{\lambda_{0.01}}{\sqrt{n}}=\frac{1.63}{\sqrt{\frac{30000}{400}}}=-0.188 .
\end{aligned}
$$

If $D_{\max }<0.157$ or $D_{\min }>-0.157$, the difference between distributions is not significant, and hence the distributions are similar. When $0.157 \leq D_{\max }<0.188$ or $-0.157 \geq D_{\min }>-0.188$, the difference between distributions is probably not significant, and when $D_{\max } \geq 0.188$ or $D_{\min } \leq-0.188$, the difference between distributions is significant, and the distributions are dissimilar. An example of calculations of the D characteristics for two 20year intervals (1951-1970 and 1991-2010, respectively) is given in Table 1. $D_{\max }$ was obtained when river flow of the respective twenty-year sub-period was lower than river flow of the multi-year 1951-2010 period, while $D_{\min }$ was obtained when river flow of the respective twenty-year sub-period was higher than river flow of the multi-year 1951-2010 period.

The testing procedure allows an assessment of similarities of discharge distributions calculated for each pentad of the consecutive twenty-year sub-periods of the multi-year period 1951-2010. The lack of similarity mans a statistically significant difference between the structure of discharges of the compared pentads of a twenty-year period and that of the initial (whole) multi-year period. Consequently, that departure from the initial multi-year pattern of flow indicates a change and destabilization of the flow regime. Additionally, this method allows determining the percent share of similar, probably similar and also dissimilar distributions for each pentad of the year and for the successive 20 -year sub- periods. As a result it is possible to determine the time when significant changes in the distribution of discharge frequencies (or disturbances of the river regime) took place, both seasonally and in the whole multi-year period. Information obtained in this way allowed classification (grouping) of the analyzed rivers in three variants, that is:

1. On the basis of the percent share of similar and dissimilar distributions in the successive 41 twenty-year periods in the multi-year 1951-2010,

2. On the basis of the percent share of similar and dissimilar distributions in the successive 73 pentads on the hydrological year, and

3. On the basis of the maximum differences in empirical distribution functions $\left(D_{\max }\right.$ or $\left.D_{\min }\right)$.

In classification of the investigated rivers the Ward's method of hierarchical grouping was applied. The Ward's method is one of the most popular ways of deriving clusters of similar elements. Ward (1963) suggested that at each step of the analysis, the loss of information associated with merging objects was measured by the sum of squares of deviations of each object from the center of the cluster to which it belongs. At each step of grouping, the union of every possible cluster pair is considered and two clusters whose function results in the lowest increase in information loss are combined. The information loss in this method is referred to as the error sum of squares (E.S.S.), defined:

$$
\text { E.S.S. }=\sum_{i=1}^{n} x_{i}^{2}-\frac{1}{n}\left(\sum_{i=1}^{n} x_{i}\right)^{2}
$$

where $x_{i}$ is the score of the $i$-th object.

The number of typological classes was determined on the basis of the dendrogram geometry and the binding distance curve. In the statistical analyses the Excel (Microsoft) and Statistica (StatSoft) software were applied, while the graphics were drawn with the help of Surfer (Golden Software) and CorelDraw 12 (Corel) tools. The isoline diagrams were con-

\begin{tabular}{|c|c|c|c|c|c|c|c|c|c|c|c|c|c|c|c|}
\hline \multirow{3}{*}{$\begin{array}{l}\text { Discharge } \\
\text { intervals }\end{array}$} & \multicolumn{9}{|c|}{ Empirical distribution functions of water discharges for chosen pentads of the year } & \multicolumn{6}{|c|}{ Values of D statistics } \\
\hline & \multicolumn{3}{|c|}{$1951-2010$} & \multicolumn{3}{|c|}{$1951-1970$} & \multicolumn{3}{|c|}{$1991-2010$} & \multicolumn{3}{|c|}{$\mathrm{F}_{1951-2010}-\mathrm{F}_{1951-1970}$} & \multicolumn{3}{|c|}{$\mathrm{F}_{1951-2010}-\mathrm{F}_{1991-2010}$} \\
\hline & $\mathrm{F}_{\mathrm{n} 1}$ & $\mathrm{~F}_{\mathrm{n} 2}$ & $\mathrm{~F}_{\mathrm{n} 73}$ & $\mathrm{~F}_{\mathrm{n} 1}$ & $\mathrm{~F}_{\mathrm{n} 2}$ & $\mathrm{~F}_{\mathrm{n} 73}$ & $\mathrm{~F}_{\mathrm{n} 1}$ & $\mathrm{~F}_{\mathrm{n} 2}$ & $\mathrm{~F}_{\mathrm{n} 73}$ & $\mathrm{~F}_{\mathrm{n} 1}$ & $\mathrm{~F}_{\mathrm{n} 2}$ & $\mathrm{~F}_{\mathrm{n} 73}$ & $\mathrm{~F}_{\mathrm{n} 1}$ & $\mathrm{~F}_{\mathrm{n} 2}$ & $\mathrm{~F}_{\mathrm{n} 73}$ \\
\hline $12.0-12.49$ & - & - & - & - & - & - & - & - & - & - & - & - & - & - & - \\
\hline$\ldots$ & $\ldots$ & $\ldots$ & $\ldots$ & $\ldots$ & $\ldots$ & $\ldots$ & $\ldots$ & $\ldots$ & $\ldots$ & $\ldots$ & $\ldots$ & $\ldots$ & $\ldots$ & $\ldots$ & $\ldots$ \\
\hline $4.5-4.99$ & 0.003 & - & - & - & - & - & - & - & - & 0.003 & - & - & 0.003 & - & - \\
\hline $4.0-4.49$ & 0.017 & - & 0.003 & - & - & - & - & - & - & 0.017 & - & 0.003 & 0.017 & - & 0.003 \\
\hline $3.5-3.99$ & 0.017 & 0.017 & 0.007 & - & - & - & - & - & - & 0.017 & 0.017 & 0.007 & 0.017 & 0.017 & 0.007 \\
\hline $3.0-3.49$ & 0.017 & 0.017 & 0.007 & - & - & - & - & - & - & 0.017 & 0.017 & 0.007 & 0.017 & 0.017 & 0.007 \\
\hline $2.5-2.99$ & 0.017 & 0.017 & 0.010 & - & - & - & - & - & - & 0.017 & 0.017 & 0.010 & 0.017 & 0.017 & 0.010 \\
\hline $2.0-2.49$ & 0.017 & 0.017 & 0.013 & - & - & - & - & - & - & 0.017 & 0.017 & 0.013 & 0.017 & 0.017 & 0.013 \\
\hline $1.5-1.99$ & 0.017 & 0.033 & 0.017 & - & - & - & - & - & - & 0.017 & 0.033 & 0.017 & 0.017 & 0.033 & 0.017 \\
\hline $1.0-1.49$ & 0.033 & 0.033 & 0.020 & - & - & - & - & - & - & 0.033 & 0.033 & 0.020 & 0.033 & 0.033 & 0.020 \\
\hline $0.50-0.99$ & 0.100 & 0.103 & 0.080 & 0.020 & 0.020 & - & 0.080 & 0.100 & 0.050 & 0.080 & 0.083 & 0.080 & 0.020 & 0.003 & 0.030 \\
\hline $0-0.49$ & 0.217 & 0.223 & 0.227 & 0.100 & 0.100 & 0.080 & 0.250 & 0.250 & 0.300 & 0.117 & 0.123 & 0.147 & -0.033 & -0.027 & -0.073 \\
\hline$-0.50-0.0$ & 0.543 & 0.620 & 0.540 & 0.380 & 0.470 & 0.350 & 0.630 & 0.680 & 0.620 & 0.163 & 0.150 & 0.190 & -0.087 & -0.060 & -0.080 \\
\hline$-1.0--0.5$ & 0.950 & 0.950 & 0.950 & 0.850 & 0.850 & 0.850 & 1.000 & 1.000 & 1.000 & 0.100 & 0.100 & 0.100 & -0.050 & -0.050 & -0.050 \\
\hline$-1.5--1.0$ & 1.000 & 1.000 & 1.000 & 1.000 & 1.000 & 1.000 & 1.000 & 1.000 & 1.000 & 0.000 & 0.000 & 0.000 & 0.000 & 0.000 & 0.000 \\
\hline
\end{tabular}
structed using the kriging procedure.

Table 1. Example of calculation of the D statistics for selected two twenty-year periods 1951-1970 and 1991-2010 (river: Warta, gauge: Poznań).

Note: the maximum values (positive or negative) are in bold 


\section{RESULTS}

\section{Changes of river regime in the multi-year period}

In order to detect spatial regularities in changes of flow regime in the multi-year period 1951-2010 the analyzed rivers were classified by the percent share of similar and dissimilar discharge distributions in the consecutive 41 twenty-year periods. In this variant of classification at the E.S.S. $=6.0$ grouping level the investigated rivers were divided into eight groups (Figure 1).

The most stable flow regime in the investigated multi-year period, reflected in the largest share of similar discharge distributions in all the 20 -year periods compared to the whole 60 year period (1951-2010), is represented by rivers of the $1^{\text {st }}$ and $2^{\text {nd }}$ group. In the case of the $1^{\text {st }}$ group the share of similar distributions is usually relatively high (on average higher than 95\%), while in the $2^{\text {nd }}$ group it is only slightly lower (between 90 and $95 \%$ ). The highest share of dissimilar distributions (up to $10 \%$ ) is observed at the beginning of the investigated period, more precisely in 1951-1970, when the flow was lower than the multi-year average and also in the $1960 \mathrm{~s}$, when it was higher than the average.

In the analyzed multi-year period changes of flow regime of rivers classified in the $3^{\text {rd }}$ group occurred in the early $1950 \mathrm{~s}$ and also in the 1970s and 1980s. In the 1950s the share of similar distributions of discharges reached $60 \%$ and the river flow was lower than the average. In the 1970s and 1980s the percent share of similar distributions of discharges was about $70 \%$, but these departures were higher than the average (Figure 2).

Rivers of the $4^{\text {th }}$ and $5^{\text {th }}$ group show the most prominent changes of flow in the investigated multi-year period. Those are streams with flow regimes most significantly changed by human activity. Rivers of the $4^{\text {th }}$ group have the largest deviations of their flow and tendency of changes similar to that of the $3^{\text {rd }}$ group. However, the scope of these changes is much broader, which is proved by very low share of similar discharge distributions. In the 1950s the flow was lower, while in the 1970s and 1980s higher than the average and the shares of similar discharge distributions were 20 and $10 \%$, respectively.
Rivers of the $5^{\text {th }}$ group, similarly to those of the $4^{\text {th }}$ group, display relatively big changes of flow in the analyzed multiyear period. However, the direction of that tendency is opposite. In the first part of the investigated period, specifically in 1951-1965, their flows are higher than the multi-year average, while in the second part (after 1975) they are lower than the average. The share of similar distributions in the two periods is very low, ranging between 10 and $40 \%$.

Rivers of the $6^{\text {th }}$ group show the highest deviations from the average values in the 1960s. Their flow values are clearly higher than the multi-year average and the share of similar distributions is about $40 \%$. In 1991-2010 there are smaller, negative deviations from the average values of flow. The share of similar distributions is relatively higher (about $80 \%$ ).

Similar changes of flow, but on a smaller scale are observed in the case of rivers of the $7^{\text {th }}$ group. In the 1960 s and 1970 s their flows were higher than the average and the share of similar distributions was about $75 \%$. In the 1990 s and 2000 s the flow was lower than the multi-year average value.

The flow of rivers of the $8^{\text {th }}$ group is higher than the average in 1951-1970 and lower after 1980. The share of similar distributions in the two periods varies from 70 to $90 \%$.

\section{Changes of river regime in the annual cycle}

Spatial regularities in changes of flow regime in the annual cycle (seasonal changes) have been analyzed on the basis of classification of the investigated rivers. The percentage of similar and dissimilar discharge distributions in the 73 five-day periods (pentads) in the successive 41 twenty-year periods of the multi-year 1951-2010 was taken as the grouping criterion. In this classification the rivers were divided into 5 groups (E.S.S. $=8.0)$ (Figure 3).

While rivers of the $1^{\text {st }}$ group have the most stable flow regime in the annual cycle, changes of flow regime of rivers classified in the $2^{\text {nd }}$ group are relatively slight and occur in the autumn-winter season (no later than mid-February) and also in June and July (Figure 4).

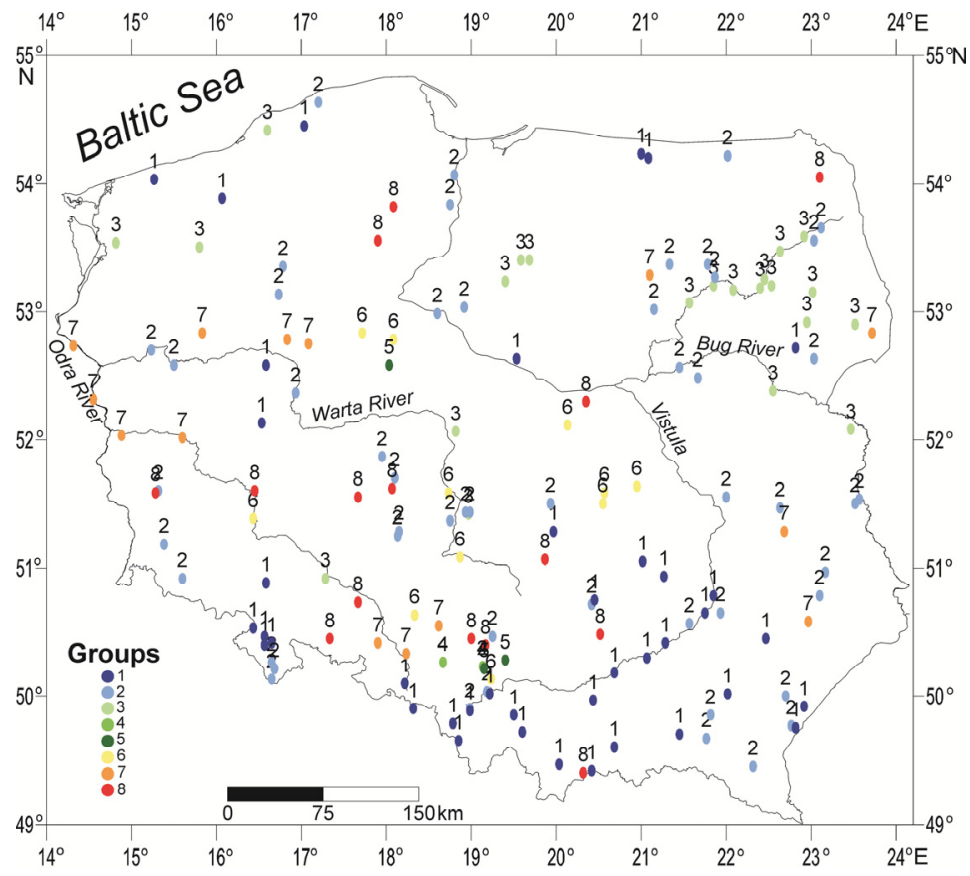

Fig. 1. Typology of rivers in Poland in terms of the proportion of similar discharge distributions in the successive 41 twenty-year intervals - the first grouping variant. 

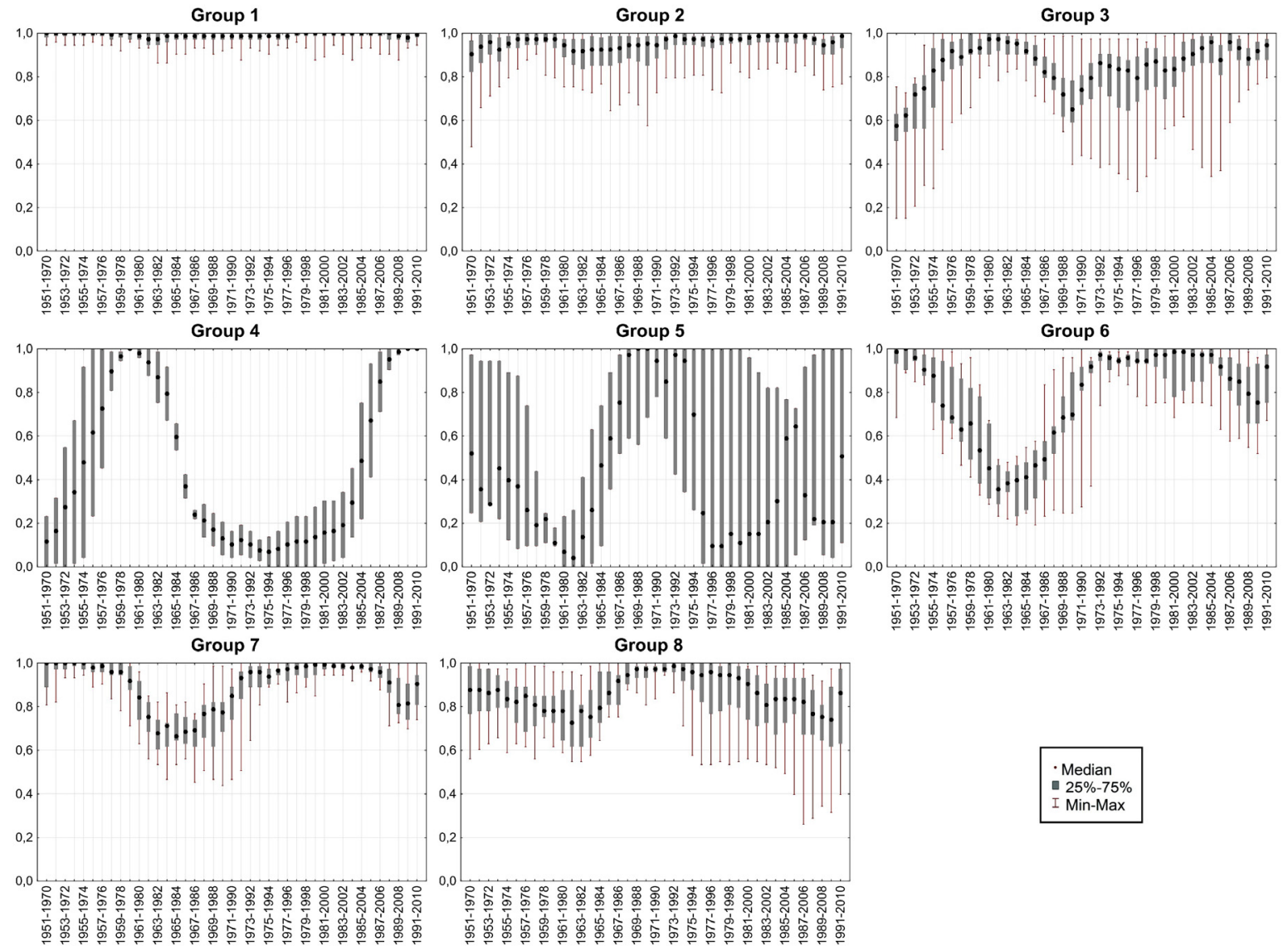

Fig. 2. Ranges of variability of the proportion of similar discharge distributions in the successive twenty-year intervals in the distinguished groups of rivers $(1.0=100 \%)$.

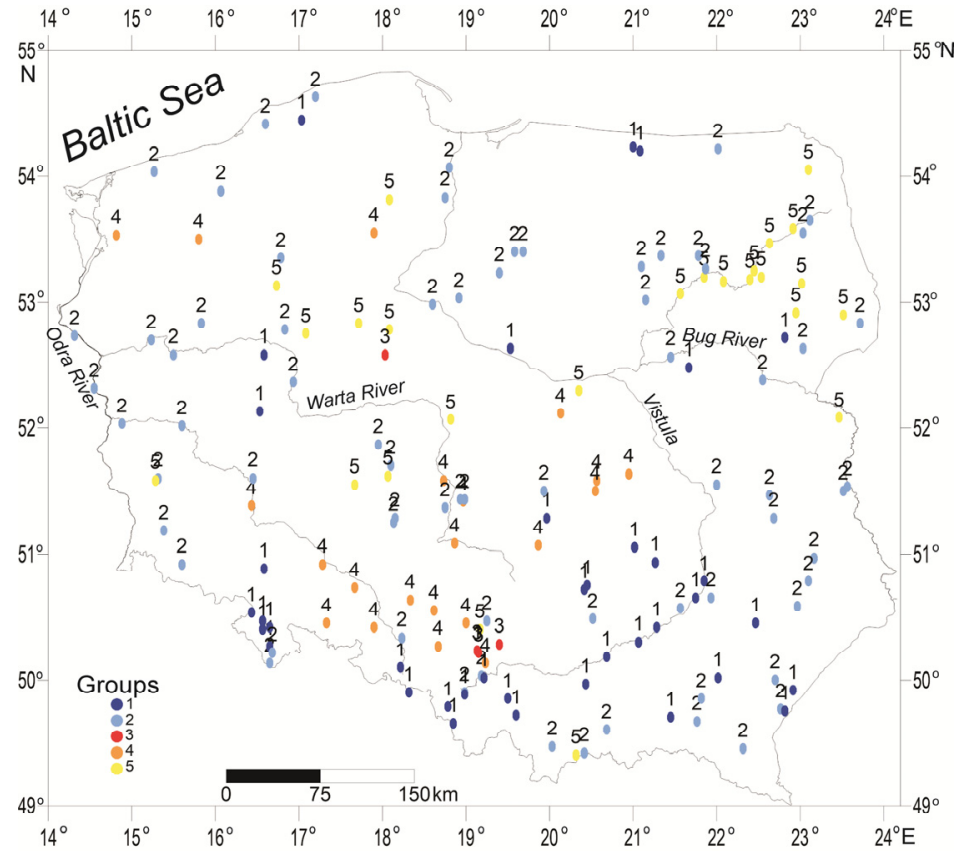

Fig. 3. Typology of rivers in Poland in terms of the proportion of similar discharge distributions in 73 pentads of the year - the second grouping variant.

The most prominent changes in the annual flow are observed in the case of rivers of the $3^{\text {rd }}$ group. While the percent share of similar distributions in the successive pentads is small (between 30 and $60 \%$ ), there is remarkably higher (about $30 \%$ ) share of dissimilar distributions resulting from an increase of flow rather than from its decrease (up to $20 \%$ ).
Rivers of the $4^{\text {th }}$ and $5^{\text {th }}$ group show more stable regimes in the annual cycle. Changes of flow of rivers belonging to the $4^{\text {th }}$ group occur at the beginning of the hydrological year (i.e. in November and December) and also in the summer-autumn period. Rivers of the $5^{\text {th }}$ group show the largest changes of flow in winter (January-February), when both its increase and de- 


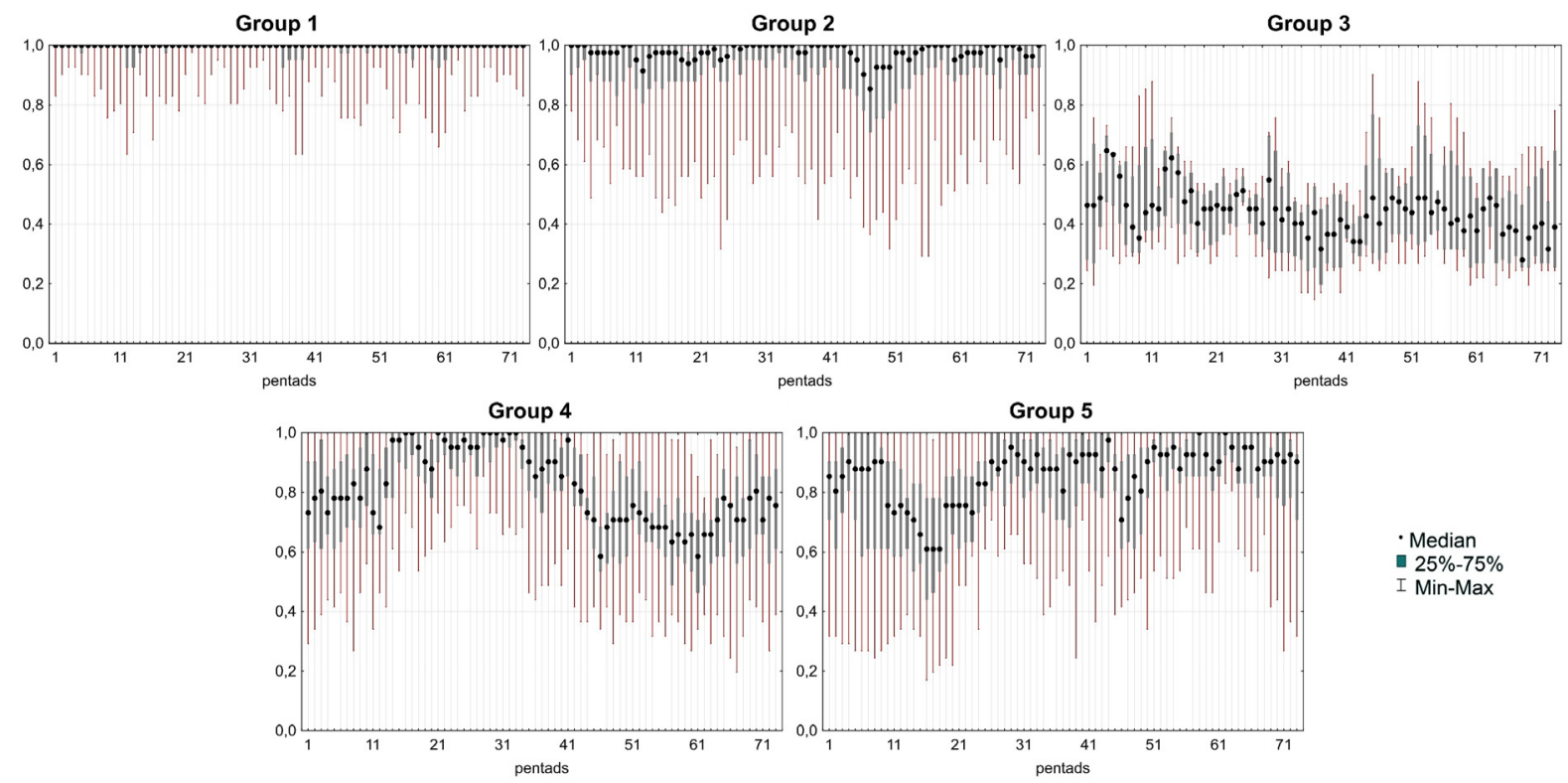

Fig. 4. Range of variability of the proportion of similar discharge distributions in 73 pentads of the year $(1.0=100 \%)$.

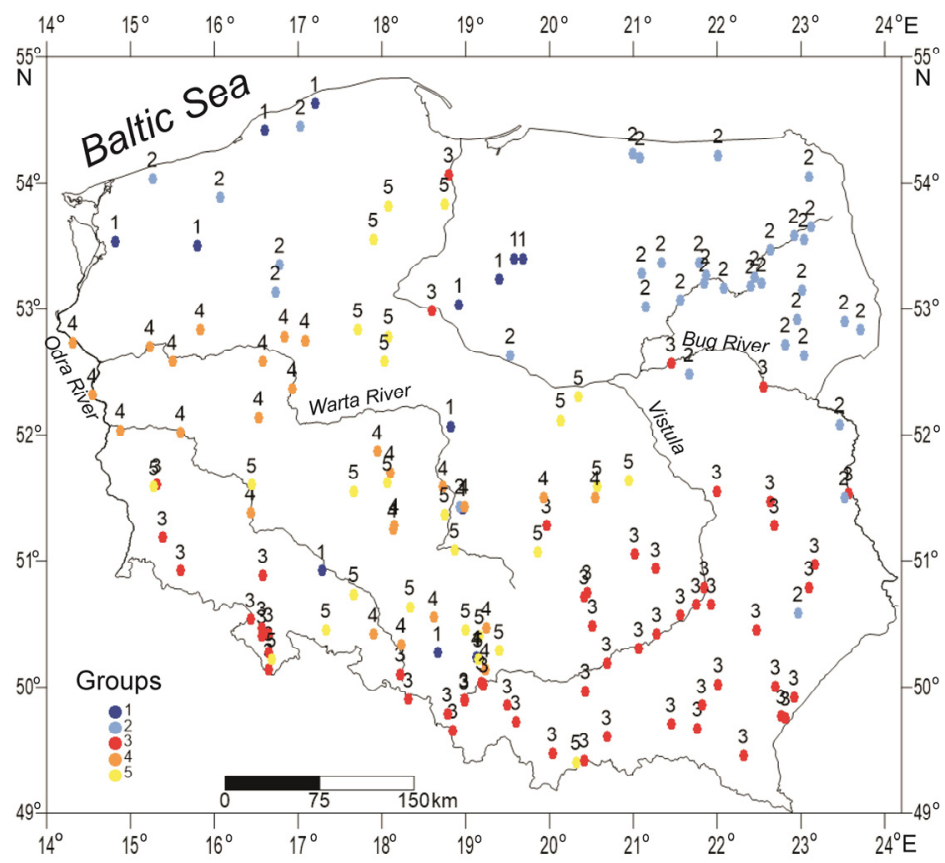

Fig. 5. Typology of rivers in Poland in terms of the similarity of the maximum differences in empirical distribution functions of the pentad sets of river flow - the third grouping variant.

crease can be observed, compared to the average flow conditions. During the other seasons, especially in summer (JuneJuly) changes of their regime are influenced mainly by positive deviations of flow compared to the average values.

The third variant of grouping seems to be most optimal and universal. In that case a comparison between the empirical distribution functions of discharges of the separated pentads in the successive 20-year periods and the multi-year (60 years) period allowed distinguishing rivers with the most unstable and stable parameters of their flow regime, both in the annual cycle and in the analyzed multi-year period 1951-2010. In that grouping variant, on the basis of a set of characteristics D at the E.S.S. $=28$ grouping level, the investigated rivers were divided into five groups, as shown in Figure 5.

Spatial distribution of the studied river gauges in the separated five groups is quite characteristic and regionally diversi- fied (Figure 5). Rivers of the $1^{\text {st }}$ group show the largest changes in their flow regimes, which are caused by human activity. They are located in different parts of Poland. In that group such rivers as the Kłodnica (at Gliwice gauge), Brynica (at Szabelnia gauge) and Czarna Przemsza in the Silesian region, the Olawa in Lower Silesia, the Ner flowing through the Lódź agglomeration, the coastal rivers Wieprza and Łupawa and also rivers of the entire hydrographic systems of the Drwęca, Ina and Drawa in the Pomeranian Lakeland can be found. They all show a decreasing flow in 1951-1970, followed by an increase in 1971-1990 (Figure 6, Figure 7). The observed changes usually take place in winter (from mid-December to mid-February) and in the summer-autumn period (from mid-June to the end of October). In the summer-autumn season values of flow higher than the average are also observed in 1981-2000. 


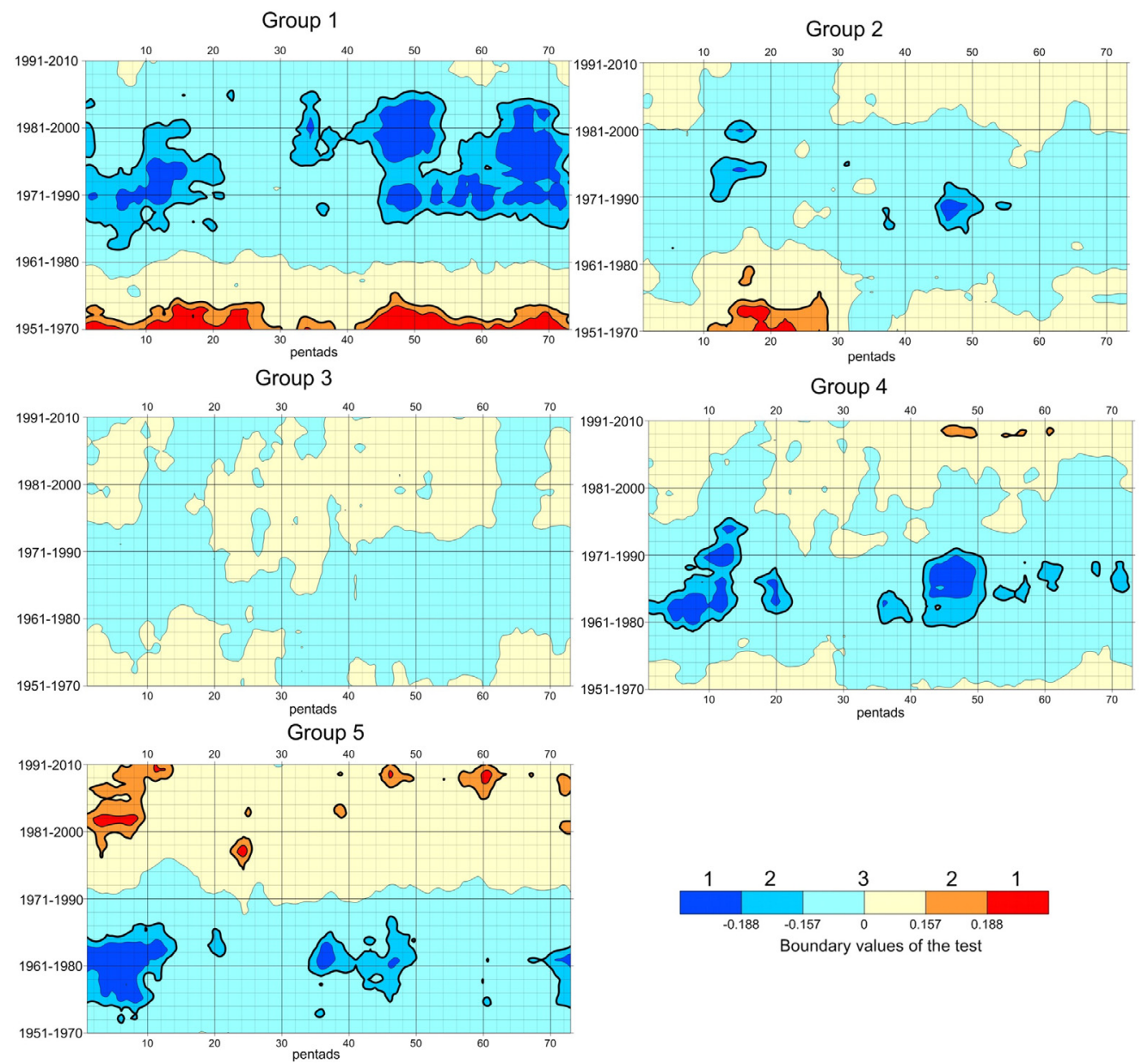

Fig. 6. Values of the maximum differences of the empirical distribution functions of the pentad sets of river flow in the successive twentyyear intervals and the significance test of their similarities in the distinguished groups of rivers ( 1 - dissimilar distributions, 2 - probably similar distributions, 3 - similar distributions).

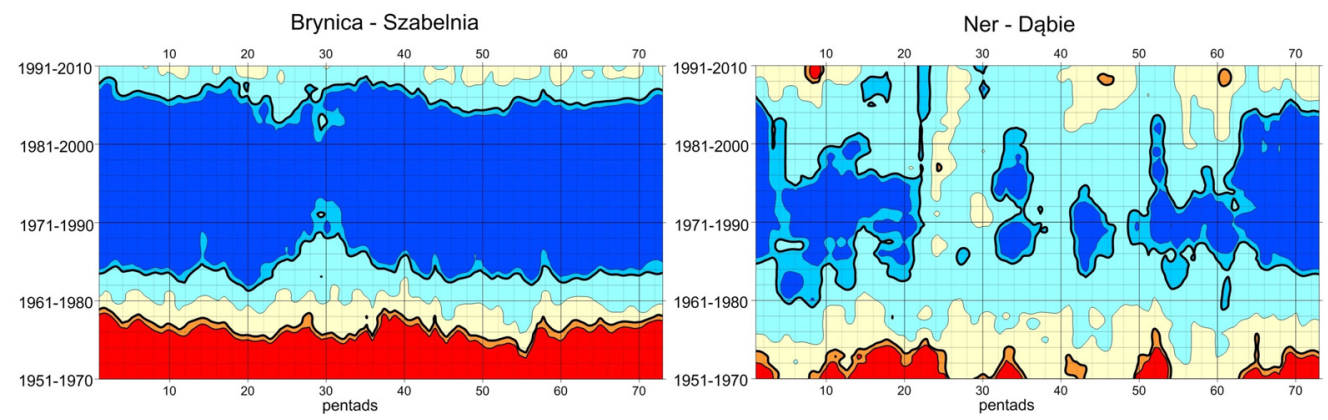

Fig. 7. Values of the maximum differences of the empirical distribution functions of the pentad sets of flow for selected rivers of group 1; legend as in Fig. 10.

In the first grouping variant rivers of the $1^{\text {st }}$ group belonged to the $3^{\text {rd }}$ group, while in the second grouping variant - to the $2^{\text {nd }}$ or $4^{\text {th }}$ group, that is with the lowest shares of similar distributions both in the 20-year periods of the analysed multi-year $\left(1^{\text {st }}\right.$ variant) and in the 5-day periods (pentads) of the annual cycle ( $2^{\text {nd }}$ variant).

In the $2^{\text {nd }}$ group there are rivers located in the northeastern part of Poland, as for example rivers of the Narew basin (with the exception of the Bug River), some coastal rivers (the Rega, Parsęta and Słupia), and the Gwda River, which flows through the Pomeranian Lakeland. In general, the flow regime of these rivers is more stable than that of the $1^{\text {st }}$ group. Nevertheless, in 1951-1970 their flows were usually lower than the average calculated for the whole investigated multi-year period, espe- cially in winter (the Narew River between January and March). On the other hand, higher values of flow are observed in the summer-autumn periods of 1970-1989, and also in the winter seasons of 1975-2000 (Figure 6, Figure 8).

Rivers of the $3^{\text {rd }}$ group represent the most stable flow regime in the investigated multi-year period. That group comprises rivers of the upper and middle parts of the Vistula River basin along with the Bug River and also tributaries of the Odra river in the Sudety Mountains (Figure 6, Figure 9), with the exceptions of the Dunajec River at Czorsztyn gauge and the Nysa Kłodzka River ( $5^{\text {th }}$ group), as well as the Wieprz River at Zwierzyniec gauge ( $2^{\text {nd }}$ group). In the previous variants they were classified as rivers having the highest share of similar discharge distributions (the $1^{\text {st }}$ and $2^{\text {nd }}$ group, respectively). 


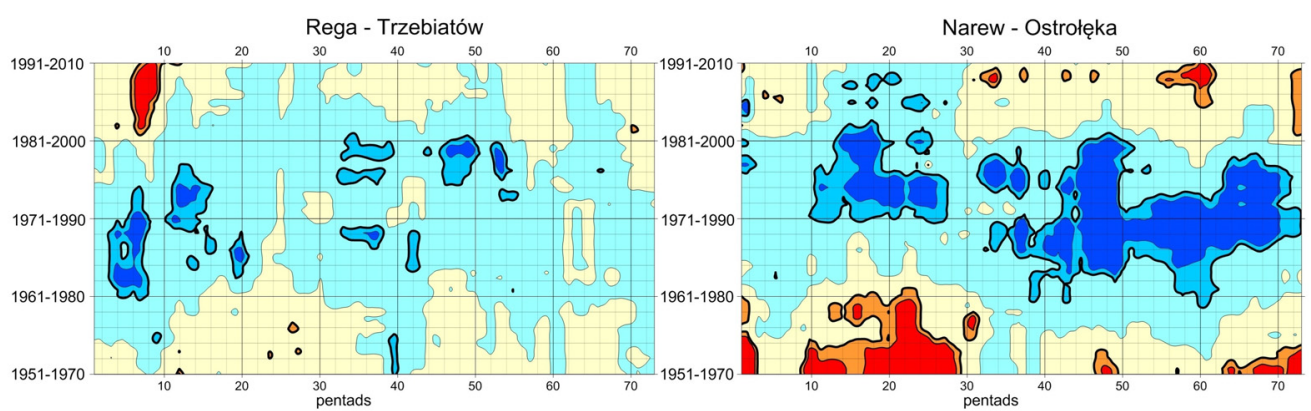

Fig. 8. Values of the maximum differences of the empirical distribution functions of the pentad sets of flow for selected rivers of group 2; legend as in Fig. 10.
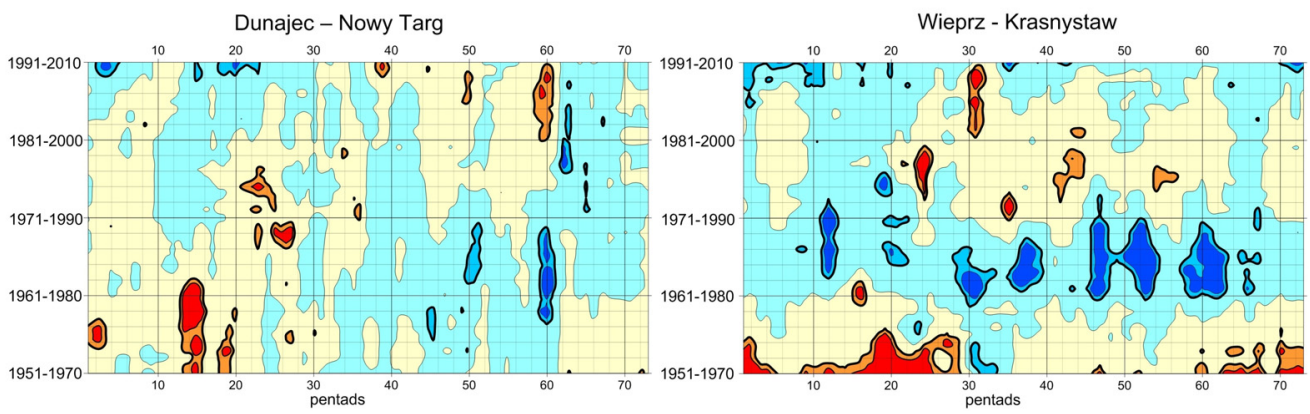

Fig. 9. Values of the maximum differences of the empirical distribution functions of the pentad sets of flow for selected rivers of group 3; legend as in Fig. 10.
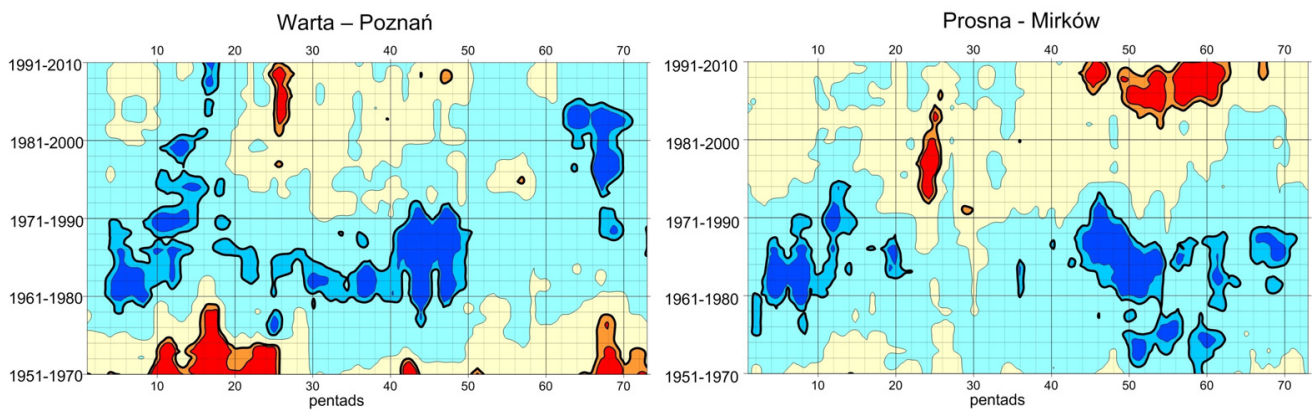

Fig. 10. Values of the maximum differences of the empirical distribution functions of the pentad sets of flow for selected rivers of group 4; legend as in Fig. 10.
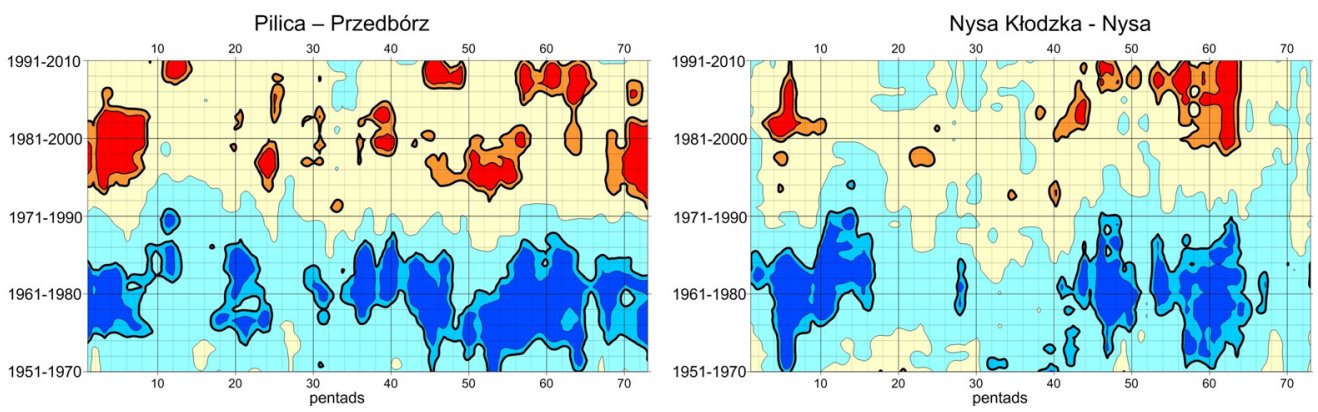

Fig. 11. Values of the maximum differences of the empirical distribution functions of the pentad sets of flow for selected rivers of group 5; legend as in Fig. 10.

The $4^{\text {th }}$ group consists of most rivers of the middle and lower sections of the Warta river basin, the middle and lower Odra river, as well as the Wolbórka and Drzewiczka rivers in the Pilica River basin. In 1961-1990 all these rivers demonstrated a noticeable increase of flow in the winter season (from December to early February) and also in late spring and early summer (from May to July) (Figure 6, Figure 10).
The $5^{\text {th }}$ group consists of rivers located in different regions of Poland, as the Silesian rivers Brynica and Biała Przemsza, the lower Nysa Kłodzka, the upper Warta with the Oleśnica River, the Barycz, Pilica, Łasica and Rawka rivers, the upper Noteć with the Gąsawka river, and the Wierzyca, Wda and Brda rivers in the lower Vistula (Wisła) basin. Generally, changes of flow observed in these rivers are varied. Between 
1951 and 1985 the flow is higher, while between 1986 and 2010 lower than the average calculated for the whole multi-year period 1951-2010. The most significant changes usually take place at the beginning of the hydrological year (that is in November and December). In 1961-1980 these rivers showed an increase, while in 1983-2002 a decrease of flow in that months. Moreover, in 1961-1980 higher flow was observed between mid-April and early July, and in some rivers also at the end of hydrological year (in October) (Figure 6, Figure 11).

\section{DISCUSSION AND CONCLUSION}

In this study changes in the flow regime characteristics of rivers in Poland were analyzed using an improved method, originally proposed by Wrzesiński in his earlier papers. This new approach not only allows identification of the exact date of these changes, but also makes possible analysis of their tendencies. Since a relatively large data set was used in the research, rivers characterized by the greatest changes in their flow conditions (as rivers of the $1^{\text {st }}$ group and - to a lesser extent $-5^{\text {th }}$ group of the third variant - Figure 6, Figure 7) in the examined multi-year period 1951-2010 were detected. Those changes are related to human activity and occur in rivers flowing through industrialized and urbanized areas, as well as in rivers with strong regulatory interference into their flow conditions. It can be concluded that the stability of flow regime of the Polish rivers is varied spatially and temporarily. Since human impact destabilizes flow conditions and their characteristics, thus the observed changes are more distinct and can be easily identified. Human activity, due to its different nature, leads to multidimensional and also spatially and temporally diversified changes of flow regime. Consequently, in the case of rivers with the disturbed flow conditions it seems to be justified to adopt as the calibration period flow characteristics from the period before the human interference rather than the average conditions from the multi-year period. For comparison, Merz et al. (2016) in their study on the temporal clustering of floods in Germany besides as long as possible time series adopted criteria of a large number of gauges for a common time period and medium and large-scale catchments to reduce the impact of human interventions on the results. In the case of the remaining groups of the investigated rivers the obtained in the third variant regional distribution is more uniform (Figure 5, Figure 6 and Figures 8-11). This may suggest greater importance of climatic conditions in modification of the flow regime characteristics, with spatial differences resulting from the regional differences of flow and the environmental characteristics (conditions) of river basins. Our findings are consistent with results of studies by Bezak et al. (2015), who concluded that the identification of trends depends on the geographical location of the analyzed streams, the local watershed characteristics and other; their analysis led to the separation of six groups of stations, based on the catchment area, seasonality coefficient and flood timescales. Similarly, the primarily role of the local characteristics in shaping the seasonality of precipitation and discharges was also proved by Parajka et al. (2009), who detected relatively larger heterogeneity of runoff than precipitation in Slovakia and Austria. Also Gaál et al. (2012), investigated river catchments in Austria as a function of climatic controls (such a storm type) and catchment controls (such as soils, soil moisture geology, land form). On this basis these authors identified 13 hot spot areas in Austria, uniform in terms of the flood generating mechanisms, but different from other regions.

Interestingly, studies on the flood regime changes of European rivers by Hall et al. (2014) proved that in Poland in the multi-year period 1921-1990 the mean and the variance of the annual maximum floods decreased and spring floods decreased for the majority of major Polish rivers. After a long period without major floods, several flood events were reported in Poland from 1997 to 2010, which results in an increase of the number of regional floods for the period 1946-2010. However, our study shows that this is not translated into an increase of the annual, seasonal and maximum flow rates in 1951-2010. In the third grouping variant rivers with the highest floods in 1997 and 2010 were classified in the $3^{\text {rd }}$ group comprising rivers with no significant changes both in the annual and multi-year periods, or in the $4^{\text {th }}$ and $5^{\text {th }}$ groups demonstrating even decreasing seasonal or annual flows in the years 1991-2010.

Our findings may provide supplementary information on the seasonal streamflow trends of the European rivers. For example, Stahl et al. (2010) analyzed datasets of near-natural streamflow records from small catchments across Europe and found positive trends over the winter months from most of them in the period 1962-2004. Our study showed an increase in the case of rivers of the north-eastern part of Poland, in the third variant classified in the $2^{\text {nd }}$ group, and also the Odra and Warta rivers with their tributaries, which belong to the $4^{\text {th }}$ group. That conclusion is supported by a distinct decline in winter flow and a delayed rise in spring meltwater flow recorded in many rivers in the 1950s and 1960s. On the contrary, in the 1970s and 1980s there were no winter base flows recorded in those rivers, normally resulting from a significant increase of winter flows, which sometimes prolong relatively lower increases of spring flows.

The observed regularities may indicate the significance of changes in the intensity of the macro-scale types of air circulation, as the North Atlantic Oscillation (NAO), which affects the hydrological cycle not only in Western Europe, but also in Poland, as it has been underlined in numerous publications (Pociask-Karteczka et al., 2002-2003; Wrzesiński, 2011, 2013a; Wrzesiński and Paluszkiewicz, 2011). Study by Dettinger and Diaz (2000) also showed that stream flow in most of the rest of Europe was higher than normal, when NAO is negative.

Moreover, the observed and projected changes of the global temperature should be considered. Labat et al. (2004) predicts that its increase by $1{ }^{\circ} \mathrm{C}$ will increase the global runoff by $4 \%$; however, the runoff trends will differ from continent to continent and no significant increasing or decreasing discharge trends is predicted for Europe. Regarding results of our study we think that in order to define the characteristics of transformations of flow regime triggered by climate change it is necessary to conduct further detailed analyses, based nor only on synchronous data, but also on those statistically uniform, which refer only to streams with the quasi-natural flow conditions.

\section{REFERENCES}

Arnell, N.W., 1999. The effect of climate change on hydrological regimes in Europe: a continental perspective. Global Environmental Change, 9, 5-23. DOI: 10.1016/S0959-3780(98)00015-6.

Bezak, N., Horvat, A., Šraj, M., 2015. Analysis of flood events in Slovenian streams. Journal of Hydrology and Hydromechanics, 63, 134-144. DOI: 10.1515/johh-2015-0014.

Bezak, N., Brilly, M., Sraj, M., 2016. Flood frequency analyses, statistical trends and seasonality analyses of discharge data: a case study of the Litija station on the Sava River. Journal of Flood Risk Management, 9, 2, 154-168. DOI: 10.1111/jfr3.12118.

Bower, D., Hannah, D.M., McGregor, G.R., 2004. Techniques for assessing the climatic sensitivity of river flow regimes. Hydrological Processes, 18, 2515-2543. DOI: 10.1002/hyp.1479. 
Dettinger, M.D., Diaz, H.F., 2000. Global characteristics of stream flow seasonality and variability. J. Hydromet., 1, 289-310. DOI: 10.1175/15257541(2000)001<0289:GCOSFS $>2.0$. CO;2.

Dynowska, I., 1971. Types of River Regimes in Poland. Zeszyty Naukowe UJ, CCLXVIII, Prace Geogr., 28, 150 p. (In Polish.)

Dynowska, I. (Ed.), 1988. Antropogenic determinants of changes in river flow and river regimes in different regions of Poland. Dokumentacja Geograficzna, 4, 95 p. (In Polish.)

Dynowska, I. (Ed.), 1993. Transformations of water relations in Poland as a result of natural and anthropogenic processes. Kraków, 463 p. (In Polish.)

Dynowska, I., Pociask-Karteczka, J, 1999. Water circulation. In: Starkel L (Ed.). Geografia Polski. Środowisko przyrodnicze. PWN, Warszawa, pp. 343-373. (In Polish.)

Gaál, L., Szolgay, J., Kohnova, S., Parajka, J., Merz, R., Viglione, A., Bloeschl, G., 2012. Flood timescales: Understanding the interplay of climate and catchment processes through comparative hydrology. Water Resources Research, 48. DOI: 10.1029/2011WR011509.

Gottschalk, L., 1985. Hydrological regionalisation of Sweden. Hydrol. Sci. J., 30, 65-83. DOI: 10.1080/02626668509490972.

Gutry-Korycka, M., Rotnicka, J., 1998. The hydrological regime of rivers in the light of scenarios of global climatic change. Geographia Polonica, Papers on Global Change, 71, 61-78.

Gutry-Korycka, M. (Ed.), 2001. Geographical Conditions of River Regimes. WGSR UW, Warszawa, 192 p. (In Polish.)

Haines, A.T., Finlayson, B.L., McMahon, T.A., 1988. A global classification of river regimes. Applied Geography, 8, 255-272. DOI: 10.1016/0143-6228(88)90035-5.

Hall, J., Arheimer, B., Borga, M., Brázdil, R., Claps, P., Kiss, A., Kjeldsen, T.R., Kriaučiūnienè, J., Kundzewicz, Z.W., Lang, M., Llasat, M.C., Macdonald, N., McIntyre, N., Mediero, L., Merz, B., Merz, R., Molnar, P., Montanari, A., Neuhold, C., Parajka, J., Perdigão, R.A.P., Plavcová, L., Rogger, M., Salinas, J.L., Sauquet, E., Schär, C., Szolgay, J., Viglione, A., Blöschl, G., 2014. Understanding flood regime changes in Europe: a state-of-the-art assessment. Hydrology and Earth System Sciences, 18, 7, 2735-2772. DOI: 10.5194/hess18-2735-2014.

Krasovskaia, I., 1995. Quantification of the stability of river flow regimes. Hydrological Sciences Journal, 40, 5, 587-598. DOI: 10.1080/02626669509491446.

Krasovskaia, I., 1996. Sensitivity of the stability of river flow regimes to small fluctuations in temperature. Hydrological Sciences Journal, $41,2,251-264$.

Krasovskaia, I., Gottschalk, L., 1992. Stability of river flow regimes. Nordic Hydrology, 23, 137-154.

Krasovskaia, I., Gottschalk, L., 2002. River flow regimes in a changing climate. Hydrological Sciences Journal, 47, 4, 597-609.

Krasovskaia, I., Sælthun, N.R., 1997. Sensitivity of the stability of Scandinavian river flow regimes to a predicted temperature rise. Hydrological Sciences Journal, 42, 5, 693-711.

Krasovskaia, I., Gottschalk, L., Kundzewicz, Z.W., 1999. Dimensionality of Scandinavian river flow regimes. Hydrological Sciences Journal, 44, 5, 705-723.

Labat, D., Godderis, Y., Probst, J.L., Guyot, J.L., 2004. Evidence for global runoff increase related to climate warming. Advances in Water Resources, 27, 6, 631-642. DOI: 10.1016/S0309-1708(04)00047-8.

Lvovich, M.I., 1938. Experience from classification of the USSR's rivers. Trudy GGI, 6, Leningrad. (In Russian.)

Merz, R., Piock-Ellena, U., Blöschl, G., Gutknecht, D., 1999. Seasonality of flood processes in Austria. In: Gottschalk, L., Olivry, J.-C., Reed, D., Rosbjerg, D. (Ed.): Hydrological Extremes: Understanding, Predicting, Mitigating. IAHS Press, Wallingford, UK, pp. 273-278.

Merz, B., Nguyen, V.D., Vorogushyn, S., 2016. Temporal clustering of floods in Germany: Do flood-rich and flood-poor periods exist? Journal of Hydrology, 541, Part B, 824-838. DOI: 10.1016/j.jhydrol.2016.07.041.

Middelkoop, H., Daamen, K., Gellens, D., Grabs, W., Kwadijk, J.C.J., Lang, H., Parmet, B.W.A.H, Schädler, B., Schulla, J., Wilke, K., 2001. Impact of climate change on hydrological regimes and water resources management in the Rhine basin. Climatic Change, 49, 12, 105-128. DOI: 10.1023/A:1010784727448.
Parajka, J., Kohnova, S., Merz, R., Szolgay, J., Hlavcova, K., Blöschl, G., 2009. Comparative analysis of the seasonality of hydrological characteristics in Slovakia and Austria. Hydrol. Sci. J. , 54, 3, 456473. DOI: 10.1623 /hysj.54.3.456.

Parajka, J., Kohnova, S., Balint, G., Barbuc, M., Borga, M., Claps, P., Cheval, S., Dumitrescu, A., Gaume, E., Hlavcova, K., Merz, R., Pfaundler, M., Stancalie, G., Szolgay, J., Blöschl, G., 2010. Seasonal characteristics of flood regimes across the Alpine-Carpathian range. J. Hydrol., 394, 1-2, 78-89. DOI: 10.1016/j.jhydrol.2010.05.015.

Pardé, M., 1957. Rivers. Warszawa, PWN, 234 p. (In Polish.)

Pociask-Karteczka, J., Limanówka, D., Nieckarz, Z., 2002-2003. The North Atlantic Oscillation impact on hydrological regime in Polish Carpathians (1951-2000). Folia Geographica, series GeographicaPhysica, 33-34, 89-104. (In Polish.)

Rotnicka, J., 1988. Taxonomic foundations of the classification of river regime (example of the Odra drainage basin and the Przymorze rivers). Seria Geografia 40, Wyd. UAM, Poznań, 130 p. (In Polish.)

Shorthouse, C., Arnell, N., 1999. The effects of climatic variability on spatial characteristics of European river flows. Physics and Chemistry of the Earth (B), 24, 1-2, 7-13. DOI: 10.1016/S14641909(98)00003-3.

Sobczyk, M., 2007. Statystyka. Wyd. Nauk. PWN, Warszawa, 417 p. (In Polish.)

Stahl, K., Hisdal, H., Hannaford, J., Tallaksen, L.M., van Lanen, H.A.J., Sauquet, E., Demuth, S., Fendekova, M., Jodar, J., 2010. Streamflow trends in Europe: evidence from a dataset of nearnatural catchments. Hydrology and Earth System Sciences, 14, 12, 2367-2382. DOI: 10.5194/hess-14-2367-2010.

Ward, J.H., 1963. Hierarchical Grouping to optimize an objective function. Journal of American Statistical Association, 58, 301, 236244.

Westmacott, J.R., Burn, D.H., 1997. Climate change effects on the hydrologic regime within the Churchill-Nelson River Basin. Journal of Hydrology, 202, 263-279. DOI: 10.1016/S0022-1694(97)00073-5.

Wilson, D., Hannah, D.M., McGregor, G.R., 2012. A large scale hydroclimatological perspective on western European river flow regimes. Hydrology Research, 44, 5, 809-833. DOI: 10.2166/nh.2012.201.

Woś, A., 2010. Climate of Poland in the Second Half of the $20^{\text {th }}$ Century. Wyd. Naukowe UAM, Poznań, 489 p. (In Polish.)

Wrzesiński, D., 2005. Changes of the hydrological regime of rivers of Northern and Central Europe in various circulation periods of the North Atlantic Oscillation. Quaestiones Geographicae, 24, 97-109.

Wrzesiński, D., 2008. Typology of spatial patterns seasonality in European rivers flow regime. Quaestiones Geographicae, 27A/1, 87-98.

Wrzesiński, D., 2010a. Spatial differentiation of the stability of the flow regime of European rivers. Seria Studia i Prace z Geografii i Geologii 3. Bogucki Wydawnictwo Naukowe, Poznań, 220 p. (In Polish.)

Wrzesiński, D., 2010b. Detection of changes in the hydrological regime of the Warta in the Poznań profile in 1822-2005. In: Wrzesiński, D. (Ed.): Odpływ rzeczny i jego regionalne uwarunkowania. Bogucki Wydawnictwo Naukowe, Poznań, pp. 135-152. (In Polish.)

Wrzesiński, D., 2011. Regional differences in the influence of the North Atlantic Oscillation on seasonal river runoff in Poland. Quaestiones Geographicae, 30, 3, 127-136. DOI: 10.2478/v10117-011-0032-y.

Wrzesiński, D., 2013a. Entropy of river flows in Poland. Studia i Prace z Geografii i Geologii 33. Bogucki Wydawnictwo Naukowe, Poznań, 204 p. (In Polish.)

Wrzesiński, D., 2013b. Flow regime transformations of rivers in Poland. In: Borówka, R.K., Cedro, A., Kavetsky, I. (Eds.): Contemporary Problems of Geographical Research. PPH ZAPOL Dmochowski, Sobczyk Sp.j., Szczecin, pp. 59-69. (In Polish.)

Wrzesiński, D., Paluszkiewicz, R., 2011. Spatial differences in the impact of the North Atlantic Oscillation on the flow of rivers in $\mathrm{Eu}-$ rope. Hydrological Research, 42, 1, 30-39. DOI: 10.2166/nh.2010.077.

Received 15 February 2017 Accepted 7 July 2017 